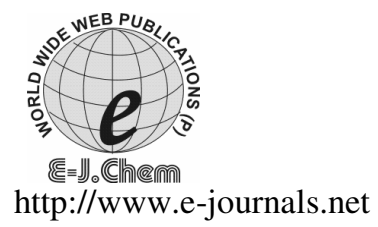

\title{
Synthesis of Benzimidazole Derivatives: As Anti-hypertensive Agents
}

\author{
JAT RAKESH KUMAR*, JAT JAWAHAR L ${ }^{\ddagger}$ and D. P. PATHAK \\ *Department of Pharmaceutical Science \\ Guru Jambheshwar University \\ Hisar-125001 \\ Department of Chemistry \\ M.L. Sukhadia University, Udaipur (Raj.)-313001. India
}

Received 11 July 2006; Accepted 22 August 2006

\begin{abstract}
A new series of non peptide angiotensin(A-II) receptor antagonist has been prepared. This $\mathrm{N}$-(biphenyl methyl) imidazoles e.g. 5-substituted (amino) -2phenyl-1-(2'carboxy biphenyl-4-yl) benzimidazoles differ from the previously reported and related compounds in that they produce a potent hypertensive effect upon oral administration. The earlier series were generally active only when administered intravenously. It has been found that 2'-position of biphenyl is essential. Only ortho substituted acid possess both high affinity for the AII receptor and oral anti-hypertensive potency.
\end{abstract}

Keywords: Benzimidazole Derivative, Anti-hypertensive agent, Synthesis

\section{Introduction}

The renin-angiotensin system $\left(\mathrm{RAS}^{1}\right)$ is known to play an important role in cardiovascular regulation $^{2}$ and the maintenance of blood pressure and electrolyte balance. AngiotensinII ${ }^{3}$ (AngII) is active hormone of RAS and it mediates a variety of physiological functions through stimulation of specific receptors. There are at least two distinct receptor sub-types ${ }^{4-5}$ designed as $\mathrm{AT}_{1}$ and $\mathrm{AT}_{2}$. The $\mathrm{AT}_{1}$ receptor mediates most of the known AngII physiologic functions such as vasocontriction and aldosterone release. The potential role for non peptide 
AngII receptor antagonists in the treatment of hypertension has well been demonstrated by $\mathrm{AT}_{1}$-selective AngII such as losartan The physiological functions of $\mathrm{AT}_{2}$ receptor are not clearly defined but $\mathrm{AT}_{2}$ receptor mediated effects of AngII have been implicated in renal free water clearance ${ }^{6-7}$. AngII receptor antagonists are expected to have similar therapeutic effects and indications as the ACE inhibitors without unwanted side effects associated inhibition of other ACE mediated pathways,such as bradykinin metabolism.Intial research in this area led to the discovery of peptide analog such as saralasin $\left(\left[\operatorname{sar}^{1}-\mathrm{Ala}^{8}\right]-\mathrm{AngII}\right)$ which displayed potent and selective AngII receptor antagonist activity both in vivo and in vitro.However, these peptides had limited therapeutic utility due to partial agonist activity short duration of action and lack of appreciable oral bioavailability ${ }^{8}$.Only in recent years a number of non peptides AngII antagonists that show promise as inhibitors of the RAS been reported ${ }^{9}$.All these antagonists possess a central aromatic nucleus bearing the pharmacophores indispensable for activity and notably a polar function adjustant to biphenyl substituents while a polar function in this area of molecule seems to be necessary to maintain activity ${ }^{10}$.

\section{Experimental}

Melting points were determined in open capillary tubes and are uncorrected. The time required for completion of the reaction was monitored by TLC using Silica gel-G plates and spots were exposed in iodine chamber. IR spectra were recorded on a Perkin Elmer 1800 (FTIR) spectrometer ${ }^{1} \mathrm{H}$ NMR spectra (DMSO) were taken on a DRX-300 spectrometer (300 $\mathrm{MHz}$ ) using TMS as internal standard and chemical shifts are expressed in $\delta \mathrm{ppm}$.

First we synthesized 2-phenyl Benzimidazole. In this method the reactants are condensed in the presence of an oxidant such as cupric acetate ${ }^{11}$. An improvement on the conventional method is the use of sodium bisulfite addition adduct of the aldehyde ${ }^{12}$. The reactions are carried out in boiling ethanol,yields are good [e.g. 2-phenyl (90\%), 2-(3pyridyl) (97\%)] and there is little risk of decomposition of liable substituents.

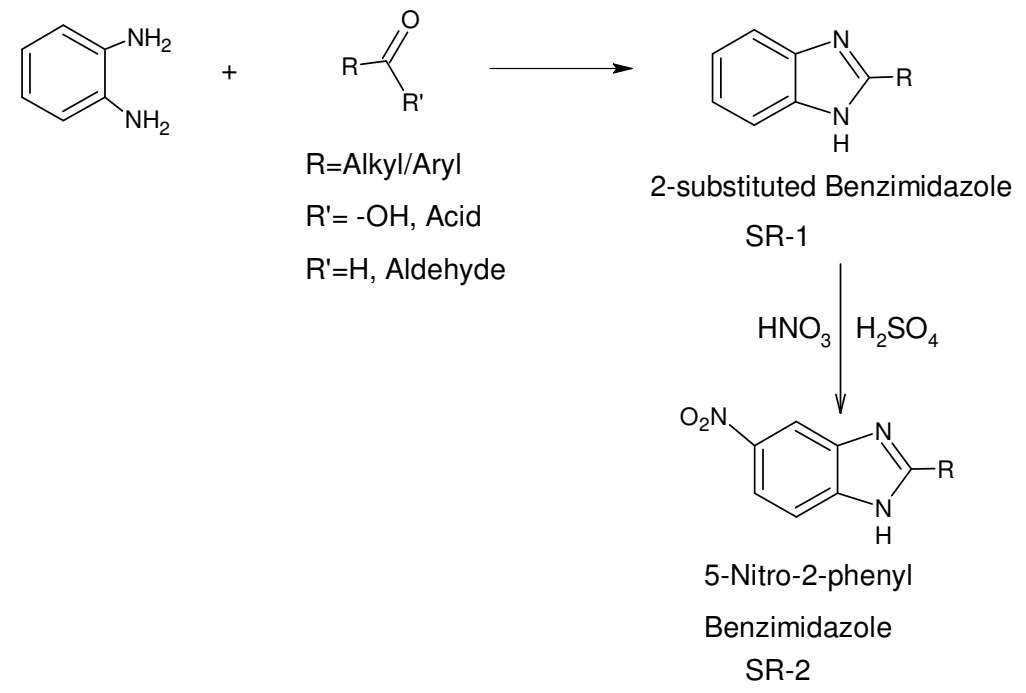

Scheme - 1 


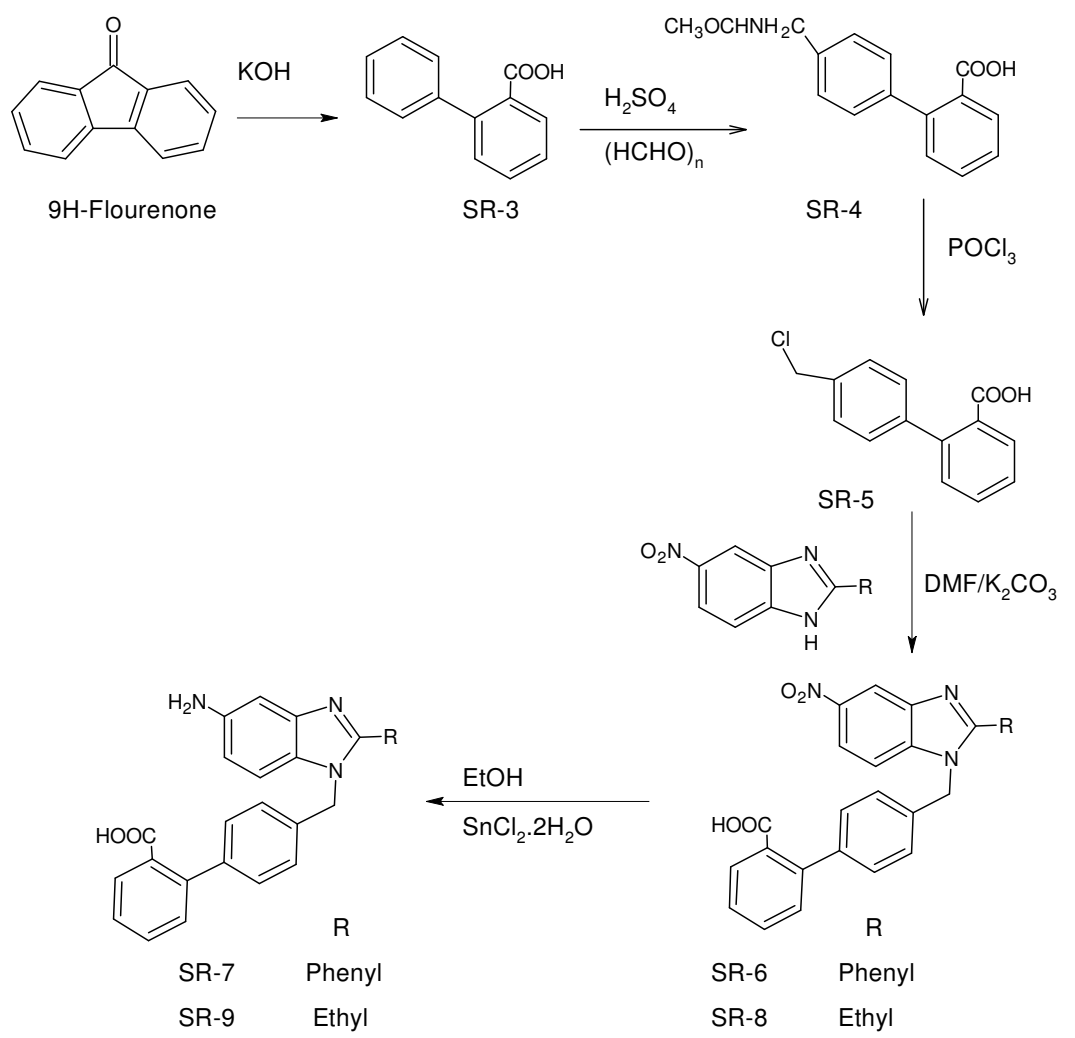

\section{SR-1: (2-phenyl Benzimidazole)}

Scheme - 2

o-Phenyl diamine $(2.7 \mathrm{gm})$ was dissolved in a mixture of methanol/water $(200 \mathrm{ml}, \mathrm{v} / \mathrm{v}$ 1:1).To this, benzaldehyde $(5.3 \mathrm{gm})$ in methanol $(50 \mathrm{ml})$ and $\mathrm{Cu}(\mathrm{OAc})_{2} \mathrm{H}_{2} \mathrm{O}(7 \mathrm{gm}$ in water $(100 \mathrm{ml})$ were added sequentially while stirring the solution. The reaction mixture was then heated to reflux under vigorous stirring for three hours after this a raddish pale precipitate was formed. The mixture was filtered hot and then washed with water to afford a yellow solid. The precipitate was redissolved in ethanol $(150 \mathrm{ml})$ and to this, $\mathrm{HCl}(24 \mathrm{ml})$ and solution of $\mathrm{Na}_{2} \mathrm{SxH}_{2} \mathrm{O}$ was added in water $(100 \mathrm{ml})$. At this stage, the reaction mixture was heated at reflux for 1 hour, resulting in the formation of black slurry. Reaction mixture was allowed to cool to room temperature and filtered through a pad of celite to remove the precipitated CuS.The filtrate was treated with ammonia solution to $p \mathrm{H} 8-9$ and then concentrated to yield a reddish pale precipitate. After filtration and vacuum evaporation, compound we were obtained as reddish solid.

Yield: $72 \%$, MP $256-258^{\circ} \mathrm{C}$, IR (KBr) $\left(\mathrm{cm}^{-1}\right)$ : 3390-3462 N-H str.), 3150 (ArH str.),16501550 ( $\mathrm{C}=\mathrm{C} \& \mathrm{C}=\mathrm{N}$ str.), 750 ( monosub. Benz. Ring). $\mathrm{H}^{1} \mathrm{NMR}(\mathrm{DMSO})$ : 9.5, (s, br., NH); 8.12-7.7 (m, 4H, ArH), 7.03-7.55 ( m, 5H, ArH). 


\section{SR -2: (5-Nitro 2-phenyl Benzimidazole)}

$10.75 \mathrm{ml}$ of concentrated nitric acid was placed in three necked flask and equal quantity of concentrated sulphuric acid (1:1) was added slowly. The mixture was kept in the ice cold water then compound SR No. 1 (6.72gm) was mixed in portions during $1 / 2$ hour under room temperature. After stirred continuously for 12 hours 45 minutes and then the reaction mixture was poured slowly over crushed ice with stirring. The precipitated product was filtered out and washes with cold water. The final product SR-2 was formed as yellowish pale.

Yield: $7.8 \mathrm{gm}(88 \%)$.

IR (KBr) $\left(\mathrm{cm}^{-1}\right): 3420$ (NH str.), 3080(ArH str.), 1640-1560 (C=C,C=N str.), 1538-1329 (N$\mathrm{O}$ str. $\left.\mathrm{NO}_{2}\right), 756$ (1,2-disubstituted benz.).

$\mathrm{H}^{1} \mathrm{NMR}(\mathrm{DMSO}): 9.3$ (s,1H, NH), 7.90-8.23 (m,3H, ArH), 7.66 ( m, 5H, ArH).

\section{SR -3: (Biphenyl Carboxylic acid)}

$15 \mathrm{gm}$ of potassium hydroxide was heated at $180^{\circ}-200^{\circ} \mathrm{C}$ in a three necked flask until fusion. $5 \mathrm{gm}$ of finely powdered of $9 \mathrm{H}$-Fluorenone was added in five portions over thirty minutes with vigorous stirring and the temperature was maintained at $180^{\circ}-200^{\circ} \mathrm{C}$ for further half hour. The fusion mixture was then poured in ice cold water with stirring. The obtained suspension was filtered at pump and then filtrate was acidify with $\mathrm{HCl}$ to $\mathrm{pH}-5$ resulting in precipitation of byproduct which was filtered under suction wash with distilled water and the filtrate was again acidify with concerated $\mathrm{HCl}$. The precipitated product was filtered under suction and dried in air. The product was recrystallized from $\mathrm{CCl}_{4}$ (Carbon tetra chloride). Product SR-3 was formed as whitish.

Yield: $4.5 \mathrm{gm}(81 \%)$. m.p. $=106-108^{\circ} \mathrm{C}$.

IR (KBr): 3600-2750 (OH Str.), 3060-3020 (Aromatic, C-H str.), 1760 (Carboxylic, C-O str.), 746 ( monosub. Benz. Ring).

$\mathrm{H}^{1}$ NMR (DMSO): $\delta 9.03(1 \mathrm{H}, \mathrm{s}$, broad, OH), $7.9(5 \mathrm{H}, \mathrm{m}, \mathrm{J}=9.0 \mathrm{~Hz})$.

\section{SR-4: (4'Acetamido methyl biphenyl-2-caboxylic acid)}

$1 \mathrm{gm}$ of SR-3 was dissolved in $6.6 \mathrm{ml}$ of concentrated $\mathrm{H}_{2} \mathrm{SO}_{4}$.After that acetamide $(0.89 \mathrm{gm})$ and Paraform aldehyde (0.075) gm were added subsequently. The solution was heated at $55^{\circ} \mathrm{C}$ along with stirring for 3 hours. The hot mixture was poured over ice and cold water. The resulting solid was filtered out.

Yield : $50 \mathrm{mg}(21.2 \%)$ m.p. $-142^{0}-144^{\circ} \mathrm{C}$.

IR (KBr) 3500-3300 (Broad O-H and N-H stretching), 2958 (C-H str, $\left.\mathrm{CH}_{3}\right), 2840$ (C-H str., $\mathrm{CH}_{2}$ ), 1756 (Carboxylic, C-O str.), 1636 (C=O str.,Amide), 846 (1,4 disub. Benz. Ring).

$\mathrm{H}^{1}$ NMR(DMSO): $\delta 9.1(\mathrm{~s}, 1 \mathrm{H}, \mathrm{OH}), 7.4-7.65(\mathrm{~m}, 8 \mathrm{H}, \mathrm{ArH}), 4.46\left(\mathrm{~s}, 2 \mathrm{H}, \mathrm{CH}_{2}\right), 2.10$ $\left(\mathrm{s}, 3 \mathrm{H}, \mathrm{CH}_{3}\right)$.

\section{SR-5: (4'Chloromethylbiphenyl-2-carboxylic acid)}

$1.4 \mathrm{gm}$ of SR-4 was taken in a RBF. $1.598 \mathrm{gm}$ of phosphorus oxy chloride was added to $4 \mathrm{ml}$ of DMF and further addition of xylene $(4 \mathrm{ml})$. The reaction mixture was refluxed for $7 \mathrm{k} / 2$ hours. The cold solution was washed with water and evaporated to give a light yellow crystalline product.

Yield: $400 \mathrm{mg}$, m.p. $=122^{0}-124^{0} \mathrm{C}$. 
IR(KBr) : 3750-3125 (Broad O-H str.) 3125-3000 (Aromatic str.), 2875(C-H str., $\mathrm{CH}_{2}$ ), 1742 (Carboxylic, $\mathrm{C}=\mathrm{O}$ str.),1602-1454 (C=N, C=C str.), 1296 (C-Ostr),736 (1,2 disubs.benz. ring), 658 (C-Cl str.)

$\mathrm{H}^{1} \mathrm{NMR}(\mathrm{DMSO}): 8.95$ (s,1H, OH), 7.2-8.23 (m, 8H, ArH), $4.46\left(\mathrm{~s}, 2 \mathrm{H}, \mathrm{CH}_{2}\right)$.

\section{SR-6: (5-Nitro 2- phenyl-[(2'carboxybiphenyl-4-yl) methyl]Benzimidazole}

$0.4612 \mathrm{gm}$ of SR-2 was dissolved in $20 \mathrm{ml}$ of DMF (dimethyl formamide) and stirred vigorously with $1.5 \mathrm{gm}$ of potassium carbonate at $27^{\circ} \mathrm{C}$ for one hour. To the resulting mixture $0.482 \mathrm{gm}$ of SR-5 first dissolved in $20 \mathrm{ml}$ of DMF and then was added dropwise with dropping funnel in 1 hour the reaction was allowed to proceed for further 11 hours and solvent removed under vacuum. Residue was treated with $20 \mathrm{ml}$ of dilute $\mathrm{HCl}$ and extracted with ethylacetate. The orgnic layer was washed with brine solution, distilled water and dried over anhydrous sodium sulphate. The solvent was evaporated and a browish amorphous solid (SR-6) was obtained.

Yield: 0.56 gm, m.p. $=160^{\circ}-162^{\circ} \mathrm{C}$.

IR (KBr): 3625-3200 (Broad O-H str.), 2868 (C-H str., $\mathrm{CH}_{2}$ ), (1750, carboxylic, $\mathrm{C}=\mathrm{O}$ str.), 1602 ( $\mathrm{C}=\mathrm{N}$ and $\mathrm{C}=\mathrm{Cstr}$.), 1543-1332 (N-Ostr., $\mathrm{NO}_{2}$ ), 1178 (C-N str.), 830 (1,4 disub. Benz. Ring).

$\mathrm{H}^{1} \mathrm{NMR}(\mathrm{DMSO}): 9.25$ (s, br.,OH), 8.75 (m,3H, ArH), 7.12-7.65 (m, 13H, ArH), 4.01 $\left(\mathrm{s}, 2 \mathrm{H}, \mathrm{CH}_{2}\right)$.

\section{SR-7: (5-amino-2-phenyl-[(2'Carboxy biphenyl-4yl methyl]Benzimidazole)}

0.9545 gm of SR-6 was placed in three necked RBF and dissolved in anhydrous ethanol and heated to $70^{\circ} \mathrm{C}$ under reflux. To this, $2.6 \mathrm{gm}$ stannous chloride dihydrate was added with slow stirring during 45 minutes. and reaction conditions were maintained for further 7 hours. The mixture was cooled to room temperature and $\mathrm{pH}$ adjusted to 7 with $5 \%$ sodium hydroxide solution. Ethanol was removed under reduced pressure and the residue extracted with dichloromethane. The organic layer was washed with brine, distilled water then dried over anhydrous sodium sulphate. Solvent removed under vacuum. A yellowish amorphous product was obtained.

Yield: $61 \%$, m.p. $=114-116^{\circ} \mathrm{C}$.

IR (KBr): 3450-3125 (Broad, O-H, NHstr.), 3080 (Aromatic, C-H str.), 2875 (C-H str., $\mathrm{CH}_{2}$ ), 1752 (Carboxylic, $\mathrm{C}=\mathrm{O}$ str.), 1602-1454 (C=N,C=C str.), 736 (1,2 disub.benz.ring).

$\mathrm{H}^{1} \mathrm{NMR}(\mathrm{DMSO}): 9.8$ (s,1H,NH), 7.4-7.62 (m,8H, ArH), $4.45\left(\mathrm{~s}, 2 \mathrm{H}, \mathrm{CH}_{2}\right), 2.5\left(\mathrm{~s}, 3 \mathrm{H}, \mathrm{CH}_{3}\right)$.

SR-8: (5-nitro-2-ethyl-(2'-carboxybiphenyl-4-yl)methyl benzimidazole)

5-nitro-2-ethyl-benzimidazole (0.4612) was dissolved in 20ml of DMF (dimethyl formamide) and stirred vigorously with $1.5 \mathrm{gm}$ of potassium carbonate at $27^{\circ} \mathrm{Cfor}$ 1 hours.Further reaction was proceeded as in SR-6.

Yield: $68 \%$, m.p. $=156-158^{0}$.

IR (KBr):3645-3220 (Broad O-H str.), 2943 (C-H str., $\mathrm{CH}_{3}$ ), 2858 (C-H str., $\mathrm{CH}_{2}$ ), (1746, carboxylic, $\mathrm{C}=\mathrm{O}$ str.), $1622(\mathrm{C}=\mathrm{N}$ and $\mathrm{C}=\mathrm{Cstr}),. 1549-1322\left(\mathrm{~N}-\mathrm{O}\right.$ str., $\left.\mathrm{NO}_{2}\right), 1172(\mathrm{C}-\mathrm{N}$ str.), 840 (1,4 disub. Benz. Ring).

$\mathrm{H}^{1} \mathrm{NMR}(\mathrm{DMSO}): 9.3$ (s,1H,NH), 7.4-7.62 (m,8H, ArH), $4.35\left(\mathrm{~s}, 2 \mathrm{H}, \mathrm{CH}_{2}\right), 2.03\left(\mathrm{~s}, 3 \mathrm{H}, \mathrm{CH}_{3}\right)$.

SR-9: (5-amino-2-ethyl-[(2'Caboxy biphenyl-4-yl) methyl] benzimidazole)

SR-8 $(0.9545 \mathrm{gm})$ was replaced in three necked RBF and dissolved in anhydrous ethanol and heated to $70^{\circ} \mathrm{C}$ under reflux. Next steps are common to SR-7. 
Yield: $66 \%$, m.p. $=124-126^{0}$.

IR (KBr): 3643-3120 (Broad O-H str.), 2966 (C-H str., $\left.\mathrm{CH}_{3}\right), 2867$ (C-H str., $\left.\mathrm{CH}_{2}\right),(1741$, carboxylic, $\mathrm{C}=\mathrm{O}$ str.), $1632\left(\mathrm{C}=\mathrm{N}\right.$ and $\mathrm{C}=\mathrm{Cstr}$.), $1539-1328\left(\mathrm{~N}-\mathrm{O}\right.$ str., $\left.\mathrm{NO}_{2}\right), 1178(\mathrm{C}-\mathrm{N}$ str.), 848 (1,4 disub. Benz. Ring).

$\mathrm{H}^{1} \mathrm{NMR}(\mathrm{DMSO}): 9.53(\mathrm{~s}, 1 \mathrm{H}, \mathrm{NH}), 7.24-7.72(\mathrm{~m}, 8 \mathrm{H}, \mathrm{ArH}), 4.38\left(\mathrm{~s}, 2 \mathrm{H}, \mathrm{CH}_{2}\right), 2.13(\mathrm{~s}, 3 \mathrm{H}$, $\left.\mathrm{CH}_{3}\right)$.

\section{Results and Discussion}

The compounds reported in this paper SR-6, SR-7, SR-8, and SR-9 were the final compound and prepared for antihypertensive activity. Taking Losartan as lead compound we had fused the benzene ring with imidazole and coupling reaction with 4-chloromethyl biphenyl 2'carboxylic acid (SR-5) to get the resulting compounds which shows hypertensive activity. At the position 2 we took 2-phenyl and 2- ethyl. From the study it was found that compounds that contain ethyl at position -2 gave better result than 2-phenyl. In the biphenyl ring carboxylic group at ortho position is necessary for pharmacological activity. At 2' position tetrazolyl moiety had the best pharmacological activity was found in the literature. At position 5 of benzimidazole $\mathrm{NH}_{2}$ group gives good activity.

Pharmacological Investigation of benzimidazole Derivatives for anti-hypertensive activities

Procedure for development of hypertention for normotensive rats ${ }^{12}$

1. Albino normotensive rats (Wistar Strain) were taken and they were hypertensized by cholinomimetic agents for screening of all the synthesized benzimidazole derivatives for there anti-hypertensive activity. Suspension of test compounds was prepared in $1 \% \mathrm{w} / \mathrm{v}$ sodium carboxy methyl cellulose (sodium CMC) and was administered at dose level of 50 and 100 microgram $/ \mathrm{kg}$ animal body weight to different groups of five rats each. After administration of dose to animal blood pressure was measured by normotensive tail and cuff method using LE-5001 pressure meter. Measurement were done after one hour and three hours interval in step-wise manner as follows:

2. One hour after administration of drug sample, animal was shifted to the restrainer, which restricts the movement of animal.

3. The tail was cleaned with moist cotton to remove the dirty matter and talcum powder was sprayed on tail to make its surface smooth.

4. A tail cuff and pulse transducer was fixed around the tail.

5. Initially animal shows particular pulse level, when the pulse rate is within the normal range. 'STRAT' switch is put on and the recorder records the blood pressure as SBP (systolic blood pressure). DBP (Diastolic blood pressure) and MABP (mean arterial blood pressure), which is displayed on monitor. The pressure can be easily read from the pre-calibrated monitor. Once all the values are displayed the recorder is switched off and for next measurement. Some procedures are allowed once when sufficient pulse level is attained. 
Table 1. Hypertension induced in normotensive rat

\begin{tabular}{cccccccc}
\hline Compound & Exp. Animal & \multicolumn{3}{c}{ After 1 hour } & \multicolumn{3}{c}{ After 3 hours } \\
\cline { 2 - 7 } & Albino (Wistar) Rat & SBP & DBP & MABP & SBP & DBP & MABP \\
\hline \multirow{5}{*}{ SR-6 } & 1 & 142 & 108 & 125 & 158 & 102 & 120 \\
& 2 & 140 & 106 & 123 & 140 & 104 & 122 \\
& 3 & 138 & 104 & 121 & 139 & 103 & 121 \\
& 4 & 140 & 104 & 122 & 141 & 105 & 122 \\
SR-7 & 5 & 141 & 109 & 125 & 140 & 108 & 124 \\
& 1 & 144 & 108 & 120 & 140 & 105 & 118 \\
& 2 & 141 & 103 & 119 & 140 & 106 & 117 \\
& 3 & 140 & 110 & 124 & 139 & 103 & 118 \\
SR-8 & 4 & 139 & 107 & 120 & 140 & 108 & 122 \\
& 5 & 138 & 105 & 121 & 139 & 107 & 121 \\
\hline \multirow{5}{*}{ SR-9 } & 1 & 142 & 112 & 127 & 140 & 110 & 111 \\
& 2 & 140 & 110 & 125 & 140 & 112 & 123 \\
& 3 & 141 & 114 & 123 & 141 & 115 & 122 \\
& 4 & 140 & 113 & 120 & 142 & 114 & 115 \\
& 5 & 138 & 110 & 125 & 140 & 109 & 119 \\
\hline & 1 & 142 & 110 & 122 & 140 & 102 & 108 \\
& 2 & 140 & 107 & 120 & 141 & 106 & 122 \\
& 3 & 141 & 110 & 121 & 140 & 104 & 120 \\
& 4 & 140 & 105 & 111 & 141 & 104 & 122 \\
& 5 & 141 & 108 & 119 & 138 & 105 & 121 \\
\hline
\end{tabular}

Table 2. Reduction in blood pressure $(\mathrm{mm} \mathrm{Hg}$ ) at a dose of $50 \mu \mathrm{gm} / \mathrm{kg}$ animal body weight.

\begin{tabular}{cccccccc}
\hline \multirow{2}{*}{ Compound } & Exp. Animal & \multicolumn{3}{c}{ After 1 hour } & \multicolumn{3}{c}{ After 3 hours } \\
\cline { 2 - 7 } & Albino (Wistar) Rat & SBP & DBP & MABP & SBP & DBP & MABP \\
\hline \multirow{3}{*}{ SR-6 } & 1 & 130 & 103 & 112 & 122 & 97 & 105 \\
& 2 & 130 & 105 & 113 & 128 & 100 & 109 \\
& 3 & 127 & 99 & 108 & 126 & 99 & 108 \\
& 4 & 129 & 102 & 111 & 128 & 102 & 111 \\
SR-7 & 5 & 130 & 105 & 113 & 128 & 103 & 111 \\
& 1 & 131 & 106 & 114 & 130 & 104 & 113 \\
& 2 & 128 & 102 & 111 & 130 & 105 & 113 \\
& 3 & 134 & 110 & 118 & 128 & 101 & 110 \\
SR-8 & 4 & 131 & 106 & 114 & 133 & 106 & 115 \\
& 5 & 130 & 104 & 113 & 131 & 104 & 114 \\
\hline \multirow{5}{*}{ SR-9 } & 1 & 126 & 110 & 115 & 118 & 108 & 111 \\
& 2 & 124 & 109 & 114 & 120 & 110 & 113 \\
& 3 & 127 & 112 & 117 & 122 & 114 & 117 \\
& 4 & 127 & 111 & 116 & 122 & 112 & 115 \\
& 5 & 126 & 110 & 117 & 120 & 108 & 112 \\
\hline & 1 & 127 & 108 & 114 & 122 & 101 & 108 \\
& 2 & 126 & 106 & 113 & 125 & 105 & 112 \\
& 3 & 127 & 109 & 115 & 123 & 102 & 109 \\
& 4 & 125 & 104 & 111 & 124 & 103 & 110 \\
& 5 & 126 & 107 & 113 & 122 & 103 & 109 \\
\hline
\end{tabular}


Table 3. Reduction in blood pressure (mean \pm SEM) at a dose of $50 \mu \mathrm{gm} / \mathrm{kg}$ animal body weight

\begin{tabular}{ccccccc}
\hline \multirow{2}{*}{ Compound } & \multicolumn{3}{c}{ After 1 hour } & \multicolumn{3}{c}{ After 3 hours } \\
\cline { 2 - 7 } & SBP & DBP & MABP & SBP & DBP & MABP \\
\hline SR -6 & $129.2 \pm 0.58$ & $102.8 \pm 1.11$ & $111.4 \pm 0.92$ & $126.4 \pm 1.16$ & $102.2 \pm 1.06$ & $108.8 \pm 1.11$ \\
SR -7 & $130.0 \pm 0.96$ & $105.6 \pm 1.30$ & $114.0 \pm 1.14$ & $130.4 \pm 0.81$ & $104.0 \pm 0.83$ & $113.0 \pm 0.83$ \\
SR -8 & $126.0 \pm 0.54$ & $110.4 \pm 0.54$ & $115.8 \pm 0.58$ & $120.4 \pm 0.74$ & $110.4 \pm 1.16$ & $113.6 \pm 1.07$ \\
SR -9 & $126.2 \pm 0.37$ & $106.8 \pm 0.86$ & $113.2 \pm 0.66$ & $123.2 \pm 0.58$ & $102.8 \pm 0.66$ & $109.6 \pm 0.67$ \\
\hline
\end{tabular}

Acknowledgement

The author is thankful to Dr. Annish siddaqui, Reader, department of pharmaceutical chemistry, Faculaty of pharmacy, Jamia Hamdard,New Delhi who guided me during pharmacological activity of these drugs. We are also thankful to Mr. Raj Kumar Sharma Who helped me in IR and NMR interpretation and availability of IR and NMR spectrum. One of the authors (JJL) is thankful to Head, Department of Chemistry, M.L.S.U., Udaipur for providing necessary facilities

\section{References}

1. Mini L, Quan and Andrew T, J. Med. Chem. 1995, 38, 2938-2945.

2. Claud A, Bern Hart, Pierre M and Perreut, J. Med. Chem. 1993, 36, 3371-3380.

3. Quan M L, Olson R E and Carni, Bioorg. Med Chem., 1994, 4, 2011-2011.

4. Quan M L and Chiu A T $24^{\text {th }}$ National medicinal chem. Symposium Salt lake city UT June 1994 abstract 6.

5. Scaly J E and Laragh J N, Regulation of blood pressure, New York, 1990, p. 1287.

6. Herblin W F and Chice A T, J. Hypertention, 1991, 4, 299s-302s.

7. Chiu A T and HerblinW F, J. Pharmaco. Exp. Ther.1990, 252,711-718.

8. Keiser J A and Bjork F A, Pharmaco. Exp Ther. 1992, 262, 1154-1160.

9. Juniak P and Pillon A Hypertension, 1992, 20(6), 737-745.

10. Scheur D A and Perrone M H, Am. J. Physiol. 1993, 264, R917-R923.

11. Ondetti M A, J. Med. Chem. 1981, 24,355-361.

12. Badyal D K, Lata H and Dadhich A P, Ind. J. Pharm. Sci.,2003, 35,349-362. 


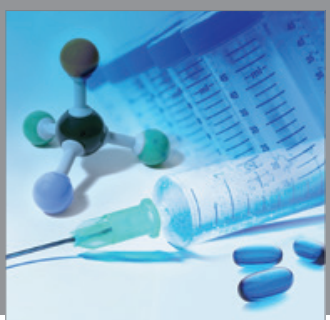

International Journal of

Medicinal Chemistry

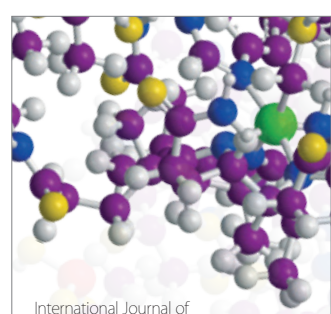

Carbohydrate Chemistry

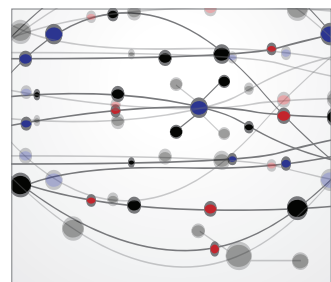

The Scientific World Journal
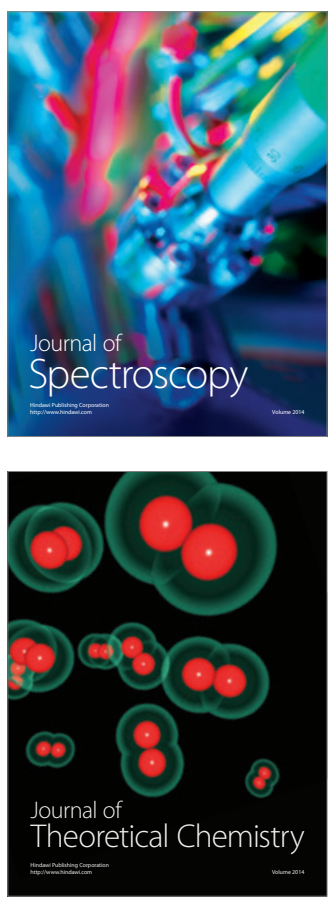
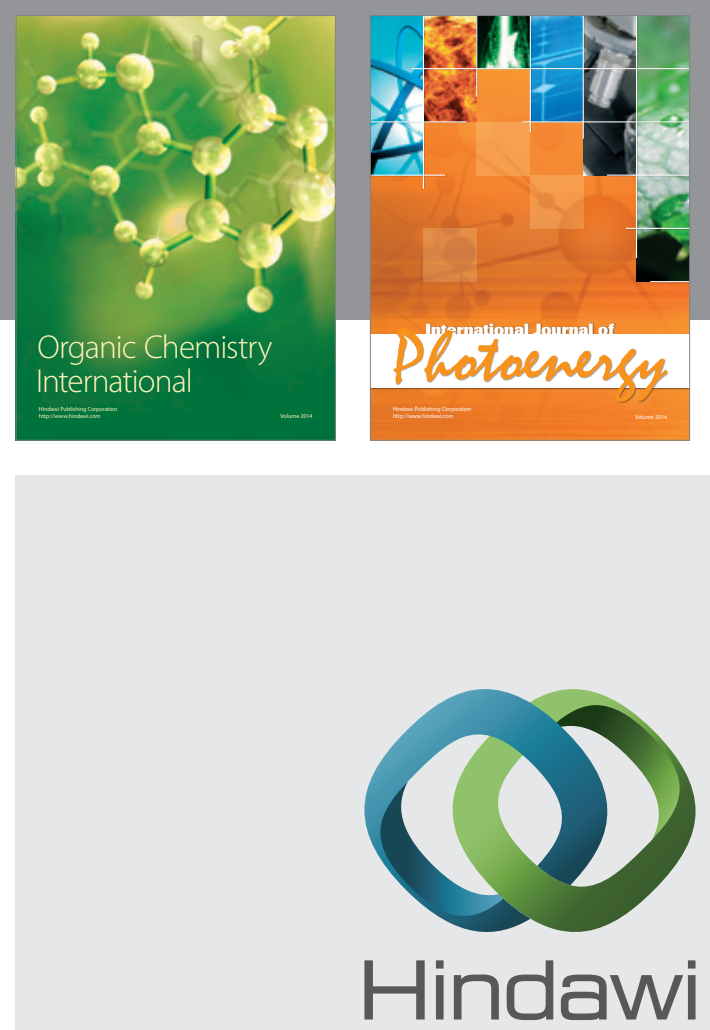

Submit your manuscripts at

http://www.hindawi.com
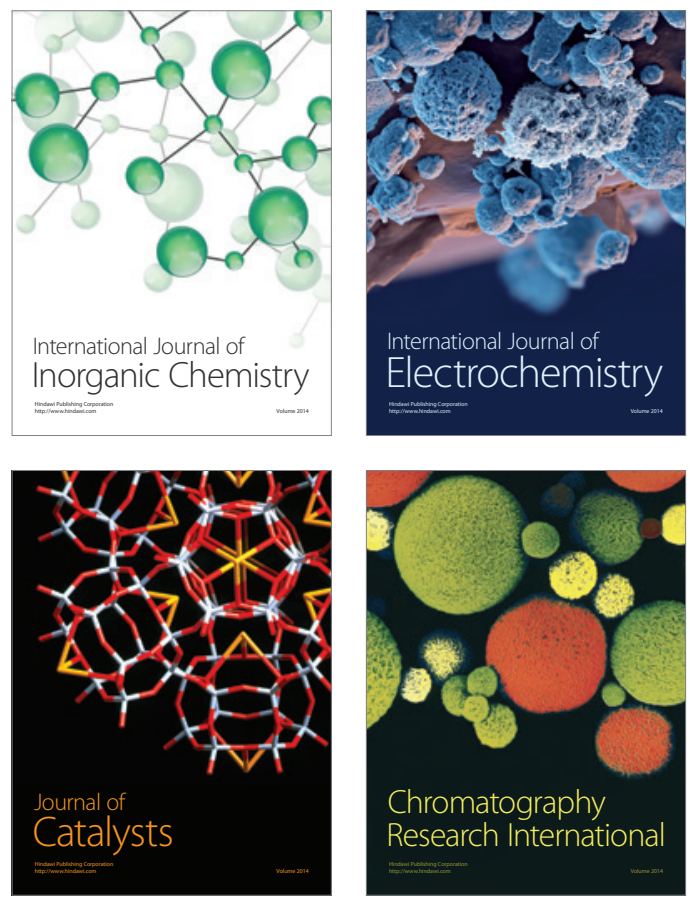
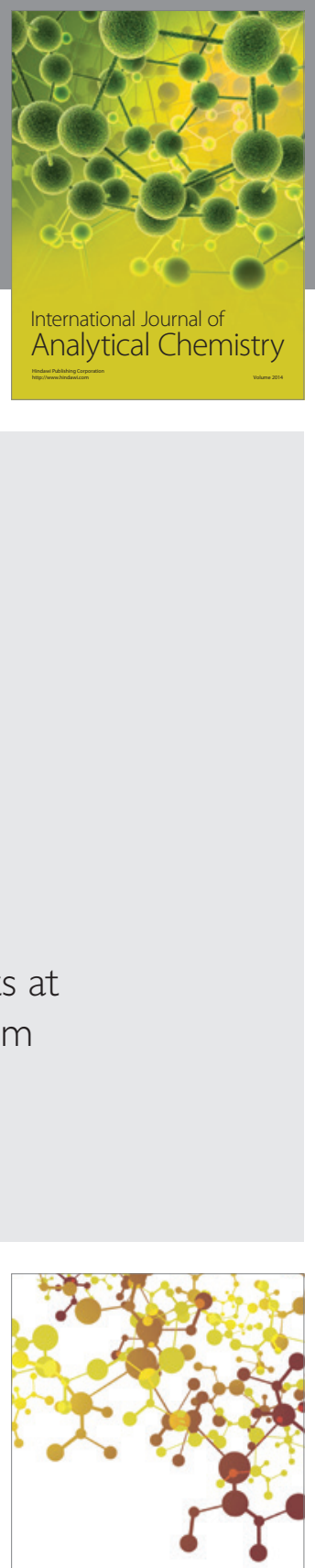

Journal of

Applied Chemistry
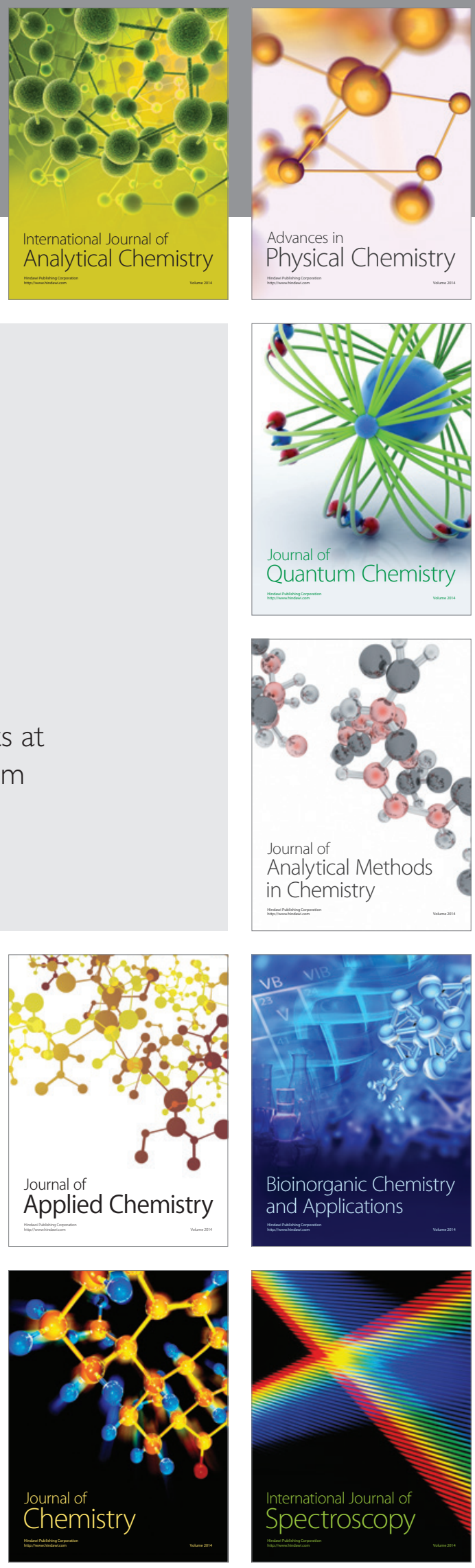